\title{
Telling Tales in Angevin Courts
}

\section{Citation}

Smail, Daniel Lord. 1997. Telling tales in Angevin courts. French Historical Studies 20(2): 183-215.

\section{Published Version}

doi:10.2307/286888

\section{Permanent link}

http://nrs.harvard.edu/urn-3:HUL.InstRepos:3716639

\section{Terms of Use}

This article was downloaded from Harvard University's DASH repository, and is made available under the terms and conditions applicable to Other Posted Material, as set forth at http:// nrs.harvard.edu/urn-3:HUL.InstRepos:dash.current.terms-of-use\#LAA

\section{Share Your Story}

The Harvard community has made this article openly available.

Please share how this access benefits you. Submit a story.

Accessibility 


\title{
Telling Tales in Angevin Courts
}

\author{
Daniel Lord Smail
}

The archives of Angevin Marseille, from the late thirteenth to the fifteenth centuries, house some of the richest court records extant from France in the later Middle Ages. ${ }^{1}$ In their wealth of detail, they approach the records of the Fournier inquisition and equal or surpass those of other late medieval French or Burgundian jurisdictions. ${ }^{2}$ They are generous, not in sheer quantity of documentation-medieval England far surpasses most regions of continental Europe in this respectbut rather in the marvelous textures and intimacies found in witness depositions. The depositions tell tales, ranging from the larger narratives of plaintiffs or defendants to the little stories of chatty witnesses. The tales tell us little about criminality; ${ }^{3}$ their value lies in what they say

Daniel Lord Smail is an assistant professor of history at Fordham University. He has published several articles on the social and cultural history of fourteenth-century Marseille and is currently working on a monograph titled Geographies of a Late Medieval City: Marseille during the Black Death, as well as a longer research project on the development of the city's judicial institutions.

It is a pleasure to thank Libby Cohen, Mireille Belloni, and two anonymous readers for their valuable suggestions and assistance.

1 Joseph Shatzmiller used one long case from Marseille's archives to great effect in Shylock Reconsidered: Jews, Moneylending, and Medieval Society (Berkeley, 1990), and Francine Michaud uses court cases involving dowry from the late thirteenth and early fourteenth centuries in $U n$ Signe des temps: Accroissement des crises familiales autour du patrimoine à Marseille à la fin du XIII ${ }^{e}$ siècle (Toronto, 1994). Economic historians have also used the archives selectively: all the important cases involving commercial disputes found in the judicial registers of the mid-fourteenth century are carefully paginated, in blue pencil, by a hand that is almost certainly that of the late Edouard Baratier, formerly the head archivist of the departmental archives of the Bouches-du-Rhône and the leading economic historian of late medieval Marseille.

2 Jean Duvernoy, ed. and trans., Le Registre d'inquisition de Jacques Fournier, évêque de Pamiers (1318-1325), 2 vols. (Paris, 1978); Emmanuel Le Roy Ladurie, Montaillou: Village occitan de 1294 à 1324 (Paris, 1975); Bronislaw Geremek, Les Marginaux parisiens aux XIVe et XVe siècles (Paris, 1976); Jacques Chiffoleau, Les Justices du Pape: Délinquance et criminalité dans la région d'Avignon au quatorzième siècle (Paris, 1984); David Nicholas, The Domestic Life of a Medieval City: Women, Children, and the Family in Fourteenth-Century Ghent (Lincoln, Neb., 1985); Claude Gauvard, "De Grace especial": Crime, état et société en France à la fin du Moyen Age, 2 vols. (Paris, 1991); Katherine Edwards, "Families and Frontiers: Urban Reaction and Recreation on the Burgundian Border" (Ph.D. diss., University of California, Berkeley, 1993); Nicole Gonthier, Délinquance, justice et société dans le Lyonnais médiéval: De la fin du XIII ${ }^{e}$ siècle au début du XVI ${ }^{e}$ siècle (Paris, 1993); Esther Cohen, The Crossroads of Justice: Law and Culture in Late Medieval France (Leiden, 1993).

3 E.g., Barbara Hanawalt, Crime and Conflict in English Communities, 1300-1348 (Cambridge, Mass., 1979).

French Historical Studies, Vol. 20, No. 2 (Spring 1997)

Copyright (C) 1997 by the Society for French Historical Studies 
about daily life, about the operations of medieval justice, ${ }^{4}$ and about legal cultures, those sets of attitudes and expectations that the judged and the judging bring to the law and the operations of justice. ${ }^{5}$

Of the many tales captured in Marseille's judicial records, few are as compelling as the tales told-or, in certain circumstances, not toldabout a great feud, an enmitas, or hatred, that wracked the city in the mid-fourteenth century. The factions that pursued the hatred took their names from two of the oldest and most powerful noble families of Marseille: the Vivaut and the Jerusalem. Thirteenth-century records are littered with references to significant ancestors of both families and to the streets and plazas that bore their names. ${ }^{6}$ By the mid-fourteenth century, in the scramble for power that followed upon the heels of the decline of Marseille's overlords, the Angevin dynasty in Naples, ${ }^{7}$ the two lineages and the factions they led were at each other's throats. In 1331, members of the Jerusalem faction wounded a Vivaut ally, the lord of Capriers, then serving as the city's subvicar. ${ }^{8}$ In 1336, they killed a servant of a judge. ${ }^{9}$ The year 1342 saw an attempt made on the life of Jacme de Galbert, a powerful noble merchant, admiral of the county of Provence, and probably another Vivaut ally. ${ }^{10}$ A huge street battle involving possibly hundreds of men exploded in July $1351 .^{11}$ In 1356 members of the Vivaut faction made up for past Jerusalem iniquities by murdering an unarmed Peire de Jerusalem, a member of the city

4 Most studies of law and justice have been developed from the perspective of legal theory, not practice; see Adhémar Esmein Histoire de la procédure criminelle en France et spécialement de la procédure inquisitoire, depuis le XIII ${ }^{e}$ siècle jusqu'à nos jours (Paris, 1882); for inquisitorial procedures in Roman law, see also Laura Ikins Stern, The Criminal Law System of Medieval and Renaissance Florence (Baltimore, Md., 1994); John K. Brackett, Criminal Justice and Crime in Late Renaissance Florence, 1537-1609 (Cambridge, 1992).

5 Thomas Kuehn, Law, Family, and Women: Toward a Legal Anthropology of Renaissance Italy (Chicago, 1991); Natalie Zemon Davis, Fiction in the Archives: Pardon Tales and Their Tellers in Sixteenth-Century France (Stanford, Calif., 1987); Guido Ruggiero, Violence in Early Renaissance Venice (New Brunswick, N.J., 1980); Guido Ruggiero and Edward Muir, eds., History from Crime (Baltimore, Md., 1994); Thomas V. Cohen and Elizabeth S. Cohen, Words and Deeds in Renaissance Rome: Trials before the Papal Magistrates (Toronto, 1993).

6 On both families, see, in general, Victor-L. Bourrilly, Essai sur l'histoire politique de la commune de Marseille des origines à la victoire de Charles d'Anjou (Aix-en-Provence, 1925). See also Edouard Baratier and Félix Reynaud, De 1291 à 1480 (Paris, 1951), vol. 2 of Histoire du commerce de Marseille, ed. Gaston Rambert, 2:692-93; references to members of both families can be found in the index to the series.

7 Georges Lesage, Marseille angevine: Recherches sur son évolution administrative, économique et urbaine de la victoire de Charles d'Anjou à l'arrivée de Jeanne $1^{\text {re }}$ (1264-1348) (Paris, 1950); Marseille et ses rois de Naples: La Diagonale angevine, 1265-1382 ed. Isabelle Bonnot-Rambaud (Aix-en-Provence, 1988); Emile-G. Léonard, Histoire de Jeanne $1^{\mathrm{re}}$, reine de Naples, comtesse de Provence (1343-1382), 3 vols. (Monaco, 1936).

8 Archives Départementales des Bouches-du-Rhône (hereafter cited as ADBR), IIIB 820,

fol. $78^{v}$. This episode was reported indirectly in testimony from the trial in 1356 .

9 ADBR, 3HD H2, liasse 1.

10 This episode is described in ADBR, IIIB 808 , fols. $123^{\mathrm{r}}-159^{\mathrm{r}}$.

11 ADBR, IIIB 811, fols. $15^{\mathrm{r}}-101^{\mathrm{v}}$. 
council and one of the city's leading nobles. ${ }^{12}$ These are but five of several dozen documented outbreaks of violence between 1331 and 1356 .

The hatred was deeply compromising. Everyone knew about it, from the nobles down to the shopkeepers, who hastily barred their doors when violence threatened on their doorsteps. Men powerful enough not to fear retaliation openly condemned it. ${ }^{13}$ Yet links of marriage and blood tied the families to most of the city's leading figures, including many members of the city council. One judge participated openly in warfare and then acted as a lawyer for his friends when the case came to court. ${ }^{14} \mathrm{~A}$ rector of the hospital of St. Esprit, the leading charitable institution of the city, was implicated in the violence. ${ }^{15}$ In 1361, Amiel Bonafos, a conspirator in the murder of Peire de Jerusalem in 1356, was so thoroughly rehabilitated that he was named one of the three city syndics. ${ }^{16}$ Even the administrators of the Angevin state were drawn into the vortex - and not only as victims, like the unfortunate lord of Capriers in 1331. The subvicar of 1355, Peire Guibert, murdered a member of the Jerusalem party and nearly lost his life in the retaliation that followed. Common opinion held that the vicarius or vicar, Marseille's chief administrator, openly favored the Jerusalem party. ${ }^{17}$ So compromising was the hatred between the Vivaut and the Jerusalem that it was never mentioned in the registers of deliberations of the city council. As a result, it cannot be found in the pages of the histories of fourteenth-century Marseille. ${ }^{18}$

12 Resulting in three trials and subsequent appeals: see ADBR, IIIB 820, fols. $1^{\mathrm{r}}-6^{\mathrm{v}}$; fols. $8^{\mathrm{r}}-$ $103^{\mathrm{v}}$; and fols. $133^{\mathrm{r}}-179^{\mathrm{r}}$.

13 E.g., ADBR, IIIB 811, fol. $72^{\mathrm{r}}$. The witness Laurens Ricau, asked by the judge inquiring into the battle of 1351 whether he openly favored any party, responded that "he wished that each party be condemned" [dixit quod vellet quod utraque pars esset condempnata].

14 This was Primar Mirapeis, a member of the Vivaut party, who was wounded in the battle of 1351. More on him below. The judges and jurists Guilhem Baxiani and Antoni Masel appear to have been members of the Jerusalem party.

15 This was the merchant Betran Johan, a member of the Jerusalem party.

16 See the record of elections in Archives Municipales de la Ville de Marseille, BB 23. This was not simply because the Vivaut faction had taken control of the city council. Peire Carbonel, Vivaut de Jerusalem, and Guilhem de Montels, all related to the Jerusalem party, were nominated to important offices on the council.

17 As several witnesses reported in the appeal of Amiel Bonafos, ADBR, IIIB 820, fols. $8^{r_{-}}$ $103^{v}$. See, for example, the testimony of the respected merchant, Peire Austria, fol. 59v: "For six months during and after his time in office the vicar preferred the party of the Jerusalem over the Martin party.... He heard many different people on the streets of Marseille saying that it seemed to them that the vicar clearly and continuously favored the Jerusalem party." [Dictus vicarius a sex mensibus citra et postquam fuit in officio favorizavit et fovit magis partem illorum de Jerusalem quam partem Martinentorum. . . . audivit dici per plateas Massilie a pluribus et diversis personis quod videbatur eis quod dominus vicarius manifeste favorisavit continue partem de Jerusalem].

18 The most prominent historian of fourteenth-century Marseille, Georges Lesage, relied primarily on these council registers in his Marseille angevine. That Marseille suffered from factional violence should come as no surprise, however. The tremendous importance of noble factions and vendettas in the organizational life of medieval cities, particularly cities of the Italian peninsula, 
At a first glance, it appears as though a Marxist model could make some sense of the conflict. In the fourteenth century, the Vivaut were rural seigneurs, lords of two villages located some miles east of Marseille, owners of important land rents in and around the city itself. The wealth of the Jerusalem, although equally based in land rents in the fourteenth century, grew out of the family's trade in armaments in the twelfth and thirteenth centuries. Yet, on tracking down the alliances that formed the larger factions, we find that they cut arbitrarily across status lines. The Martin lineage, whose fortunes were closely entwined with those of the noble Vivaut, were relative newcomers to power and prestige. The family's fortune lay in commerce; their rise to prominence began with their ancestor, the merchant Jacme Martin, who died a wealthy man in 1302. By the same token, the nobleman Isnart Eguesier was a major ally of the entrepreneurial Jerusalem. The clienteles of each party, similarly, were nearly identical in their socioprofessional backgrounds. This being so, it takes a great deal of ingenuity to force the hatred into a Marxist model. For similar reasons, Marseille's domestic politics cannot be understood according to Italian political structures, namely the intense rivalry between Guelf and Ghibelline, the parties of the papacy and the empire. The hatreds that so thoroughly curdled the society of mid-fourteenth-century Marseille were prior to any structure we might devise to explain them. The cleavages and ruptures were contingent and emotional, not structural, in origin.

In an eight-year period following the Black Death of 1348, as the violence deepened and intensified, outbreaks of the feud became the object of several judicial inquisitions. As described in the first section below, these inquisitions were directed by the Angevin-run court of inquisition (curia inquisitionis). An indeterminate ${ }^{19}$ number of these inquisitions resulted in condemnations that were subsequently appealed to the court of first appeals. Several appellate registers from the 1350s have survived the passage of time, and in these registers we find twelve appeals concerning the feud. Four of them include a transcript of the original trial. The trial transcript-written in a different hand, often on noticeably different paper-precedes the subsequent depositions of

has been underscored in a variety of recent histories. For a variety of perspectives see the recent study of Carol Lansing, The Florentine Magnates: Lineage and Faction in a Medieval Commune (Princeton, N.J., 1991), chap. 9, "Violence and Faction"; Daniel Waley, The Italian City-Republics, 3d ed. (London, 1988): 118-31; Jacques Heers, Family Clans in the Middle Ages, trans. Barry Herbert (Amsterdam, 1977), chap. 5, 169-206; Lauro Martines, ed., Violence and Civil Disorder in Italian Cities, 1200-1500 (Berkeley, Calif., 1972); and Nicholas, Domestic Life of a Medieval City, chap. 10, "Clans in Conflict," 187-206.

19 Indeterminate because the inquisition records have been lost. 
the appellate witnesses in the four cases. As one reads the cases, one moves naturally from the trial to the appeal, thereby recapitulating the original sequence of events.

To read in this way is to witness a remarkable transformation in the way tales of conflict are told: first by the prosecutor, who tells no story at all, and then by the defendants, who tell dark tales of hatred, of the inevitability of vengeance. As the second section of this article will argue, the tales reveal that vengeance in mid-fourteenth-century Marseille was or had become a language of resistance to Angevin judicial presence. It was a language whose power was implicitly recognized by judges in their attempts to destroy its syntax. It was a language, moreover, that shaped the exercise of justice more than a complacent view of legal evolution would care to admit. The third section will suggest that the courtroom was becoming or had become a venue for the pursuit of vengeance. That is not all. To judge by the cases, the very exercise of justice and power in mid-fourteenth-century Marseille was instrumental in giving shape and structure to the hatred. By allowing defendants a place for the telling of a history, the fourth section will argue, Angevin justice helped groups of unrelated men form a historical identity. By prosecuting the groups, the court helped solidify that identity in a common grievance and a common defense. Angevin justice in Marseille, then, did as much to institutionalize as it did to repress the hatreds that curdled city society, rigidifying relationships of enmity rather than dissolving them. That is not what the developing judicial systems of medieval Europe were supposed to be doing.

\section{Judicial Inquisition}

To understand the judicial appeals that form the bulk of the evidence for this article, one must understand the secular court of inquisition out of which most appeals emerged. ${ }^{20}$ Secular courts using Roman inquisitorial procedures emerged throughout southern Europe in the thirteenth century, following the sudden demise of the ordeal as a mode of proof. ${ }^{21}$ These procedures were similar to but not identical with those developed at the same time by the infamous papal inquisition; among other things, secular courts did not develop a case load based so heavily on serial and secretive accusations, nor were the accused, most of whom hired expensive lawyers to plead their cause, so

20 Two appeals, discussed below, were initiated by a cousin of the victim. In all other respects, however, they were nearly indistinguishable from trials initiated by the court itself.

21 On the relationship between ordeal and inquisition see Robert Bartlett, Trial by Fire and Water: The Medieval Judicial Ordeal (Oxford, 1988). 
defenseless. To understand Marseille's court of inquisition, however, one must first retreat a step further and address the alternative to justice: peacemaking. ${ }^{22}$ In Angevin Marseille, as elsewhere, acts of violence typically generated a ritual response, the desire for vengeance. The bloodfeud or the vendetta, where practiced, is corrosive, and often costly as well, both for avengers and for the objects of their vengeance. But vengeance can be diverted by the act of peacemaking, the very threat of vengeance used as a tool to get the aggressor to perform the necessary acts of expiation. In many regions of medieval Europe, especially from the central Middle Ages onward, the hatreds spawned by violence could be assuaged through acts of peacemaking, often directed by the church, often operating outside the confines of the newly emerging legal procedures of incipient states. ${ }^{23}$ The culture of peace had become so powerful by the fourteenth century that in France as in most regions of Europe, the feud, as a more or less interminable series of exchanges, was extremely limited in scope. ${ }^{24}$ Still, it was the continuing threat of the feud, at least in theory, that drove peacemaking. Peacemaking in Marseille and elsewhere in southern France and Europe required the exile (voluntary or involuntary) of the aggressor; the intervention of peacemakers, either members of the mendicant orders or highly respected noblemen; the payment of some compensation; and, perhaps most important, a public spectacle of contrition and forgiveness, usually involving the exchange of the kiss of peace. In the lands of the Roman law, the result of those processes was conveniently distilled in the notarial peace accord. This was a formal legal contract entered into by both parties, drawn up by a public notary, using standard notarial protocols, and witnessed by an array of significant people. Eight such peace accords have survived from Marseille across a period of twenty-five years in the mid-fourteenth century. The haphazard survival of notarial casebooks indicates that the act itself was much more common.

22 For a variety of perspectives on this see Frederic Cheyette, "Suum Cuique Tribuere," French Historical Studies 6 (1970): 287-99; Michael T. Clanchy, "Law and Love in the Middle Ages," in Disputes and Settlements: Law and Human Relations in the West, ed. John Bossy (Cambridge, 1983), 47-67; Patrick J. Geary, "Vivre en conflit dans une France sans état: Typologie des mécanismes de règlement des conflits (1050-1200)," Annales E.S.C. (1986): 1107-33; Stephen D. White, "Feuding and Peace-Making in the Touraine around the Year 1100," Traditio 42 (1986): 195-263; idem, “'Pactum . . . Legem Vincit et Amor Judicium': The Settlement of Disputes by Compromise in Eleventh-Century Western France," American Journal of Legal History 22 (1978): 281-308; Kuehn, Law, Family, and Women, 19-100.

23 See, for example, Augustine Thompson, O. P., Revival Preachers and Politics in ThirteenthCentury Italy: The Great Devotion of 1233 (Oxford, 1992); James M. Powell, Albertanus of Brescia: The Pursuit of Happiness in the Early Thirteenth Century (Philadelphia, 1992); Daniel Ethan Bornstein, The Bianchi of 1399: Popular Devotion in Late Medieval Italy (Ithaca, N.Y., 1993).

24 See, however, Charles Petit-Dutaillais, Documents nouveaux sur les moeurs populaires et le droit de vengeance dans les Pays-Bas au XV siècle (Paris, 1908). 
Given the development of increasingly sophisticated peacemaking mechanisms, judicial inquisition, even in the mid-fourteenth century, was only one of two channels through which acts of violence could be handled. ${ }^{25}$ In Angevin Marseille, inquisition was not even the most prominent channel for handling crime, at least in cases of homicide. ${ }^{26}$ The more serious the act of violence, the more likely it was that the criminal would be summarily expelled from the city-if he had not already exiled himself or sought sanctuary in a church, as many were wont to do. Marseille's statute on homicide, in fact, declared that a murderer had to make peace with four or five of the victim's kin before being allowed to return to the city; in this way, formal authority over the case was automatically transferred to the peacemaking procedure..$^{27}$ The standard notarial peace accord included a clause preventing the victim or his or her kin from pursuing any judicial redress for the act of violence, thereby making concrete the genuine distinction between the two systems.

This clause did not, of course, prevent the inquisition from initiating its own accusations in cases of violence, nor, by definition, could it restrain the unpacified victims of violence from initiating their own suits. Nonetheless, the few surviving judicial inquisitions and trials involving cases of homicide or severe wounds typically centered on incidental offenses, such as forming illicit groups, bearing arms, and sometimes traveling by night without a lantern. ${ }^{28}$ The trial of the murderers of Peire de Jerusalem in 1356, which technically was not an inquisition because the prosecution was initiated and directed by a cousin of the dead man, illustrates well this general pattern. We can assess the principal charges because the prosecutor had the relevant city statutes and public proclamations (preconizationes) pertaining to each of the charges copied out in full in the transcript. These statutes were limited to several statuti rassarum, a series of laws forbidding secret conspiracies: the most prominent was the statute "That Secret Societies and Organizations Ought Not to Be Formed" [De conjurationibus et rassis non

25 State-directed judicial inquisition, in the lands of the Roman law, allowed courts to be something more than the passive recipients of private suits, for by following inquisitorial procedures, courts could generate accusations on their own authority and assemble their own proofs. In addition to Brackett, Criminal Justice and Crime, and Stern, Criminal Law Courts, see Sarah R. Blanshei, "Crime and Law Enforcement in Medieval Bologna," Journal of Social History 16 (1982): 121-38; and John A. Langbein, Torture and the Law of Proof: Europe and England in the Ancien Régime (Chicago, 1977).

26 On this see my "Common Violence: Vengeance and Inquisition in Fourteenth-Century Marseille," Past and Present 151 (1996): 28-59.

27 Régine Pernoud, ed. and trans., Les Statuts municipaux de Marseille(Monaco, 1949), bk. 5, chap. 25, 178.

28 The situation was in fact slightly more complicated than this, because the inquisition seems to have limited the scope of its prosecution to charges such as these even in cases where no peace accord was forthcoming. 
faciendis].$^{29}$ Following that is a transcript of a "public proclamation that forbade the bearing of arms" [tenor preconizationis de armis non portandis] ${ }^{30}$ Although the actual murder was described in some of its gory details, the accusation of murder was itself oddly peripheral to the prosecution. The trial centered instead on seemingly trivial statutory infractions-crimes against the state rather than violence done to a private citizen.

The infractions, of course, were serious enough. Marseille's prosecutors were able to add another charge: peacebreaking. The notarial peace accord included a clause stipulating that those guilty of offending a peace should pay a fine of one hundred pounds or more. Any transgressions, therefore, could be prosecuted as a breach of contract. In the trial described above, arising from the murder of Peire de Jerusalem, not one but two peace accords, the first dated 24 March 1350, the second 26 July 1351, were transcribed to deepen the guilt of the murderers, members of the Vivaut party. ${ }^{31}$

What this indicates is that the court was reluctant to become involved in relationships of enmity that sprang out of a murder. The court preferred to concentrate on statutory infractions, leaving the hatred itself to the system of peacemaking. The two systems of handling violence, peacemaking and inquisition, did not operate in wholly distinct spheres, since to some extent inquisition built upon the results of peacemaking. The relationship, however, was not entirely symbiotic: inquisition could also destroy the emotional basis of peace. Condemnation, as anthropologists of law have been arguing, is the antithesis of peacemaking, and prosecution, with its all-or-nothing outcome, cannot fail to create anger. ${ }^{32}$ Seen in this light, inquisition may have interfered, at least in the short term, with the beneficent possibilities of peacemaking.

The existence of a parallel system of peacemaking, then, shaped the exercise of justice in Angevin Marseille. The exercise of justice was also influenced by its own procedures.

29 ADBR, IIIB 820, fol. $13^{v}-14^{v}$. See also Statuts municipaux, bk. 5, chap. 6, 168.

30 Ibid., fol. $15^{v}$.

31 Ibid., fols. $16^{\mathrm{r}}-21^{\mathrm{v}}$.

32 For recent studies of the anthropology of law see Lawrence Rosen, The Anthropology of Justice: Law as Culture in Islamic Society (Cambridge, 1989); June Starr and Jane F. Collier, eds., History and Power in the Study of Law: New Directions in Legal Anthropology (Ithaca, N.Y., 1989); Laura Nader, Harmony Ideology: Justice and Control in a Zapotec Mountain Village (Stanford, Calif., 1990); Peter Just, "History, Power, Ideology, and Culture: Current Directions in the Anthropology of Law," Law and Society Review 26 (1992): 373-411. See also the useful discussion in Kuehn, Law, Family, and Women, 19-21. 
An inquisition in fourteenth-century Marseille proceeded, it seems, only if the malefactors were caught in flagrante delicto. The police force necessary to capture criminals was supervised by an Angevin official known as the subvicar. Like all major Angevin officials and judges, that officer was a foreigner to the city; like his superior the vicar, the subvicar was usually a nobleman of Provence. In various records, we see that official, accompanied by a private force of armed men, arresting and sometimes abusing the citizens of Marseille. If the crime were serious enough, he would take them off to the prison, located near or underneath the royal curia on a street south of the plaza of Accoules. Some defendants were allowed to await trial in their own homes-with the understanding that all their possessions in Marseille would be forfeit should they fail to respond to the eventual summons. Immediately after the event or at most within a month, the case was brought before a judge. This man, the palace judge, presided over the highest court of first instance for both civil and criminal affairs. As inquisition judge (iudex inquisitionis), he was assisted by two lesser judges; accompanied by several notaries, those men formed the court of inquisition (curia inquisitionis). In the street outside the royal palace, or possibly within the building itself, they took testimony from witnesses and formally interrogated each of the defendants in turn. Some of the defendants were tortured in the basement of the palace before interrogation. ${ }^{33}$ Evidence permitting, the judge then condemned the defendants according to his own assessment of their crimes, and the decision was subsequently announced, formally and publicly, in the name of the vicar at public parlements, held five or six times a year in the nearby plaza of Accoules. Defendants were never allowed to present a formal defense, other than the limited denial they could offer during testimony.

All cases could be appealed, however, and it was during the appeal that defendants were finally able to tell their side of the story. An appeal usually began with arguments over the permissibility of the appeal; following that came a transcript of the inquisition trial. Following court rules that were identical to civil procedures, defendants then offered a list of titles or tituli (tenor titulorum) to prove their innocence and a list of witnesses to testify to the titles. ${ }^{34}$ The largest section

33 In the pages of one appeal arising from an inquisition that began in November 1351, we can see all three judges - the palace judge, Johan Symeon, accompanied by the two lesser judges, Guilhem de Montoliu and Johan de Quinciato-supervising the torture of an immigrant suspected of homicide (see ADBR, IIIB 811, fols. $3^{v}, 7^{v}$ ). Marseille's inquisition used the torture horse (eculeum) and seems to have employed it most commonly with lower status defendants.

$34 \mathrm{~A}$ very few appellate transcripts at this point include a list of questions that the judges intended to pose to the witnesses. 


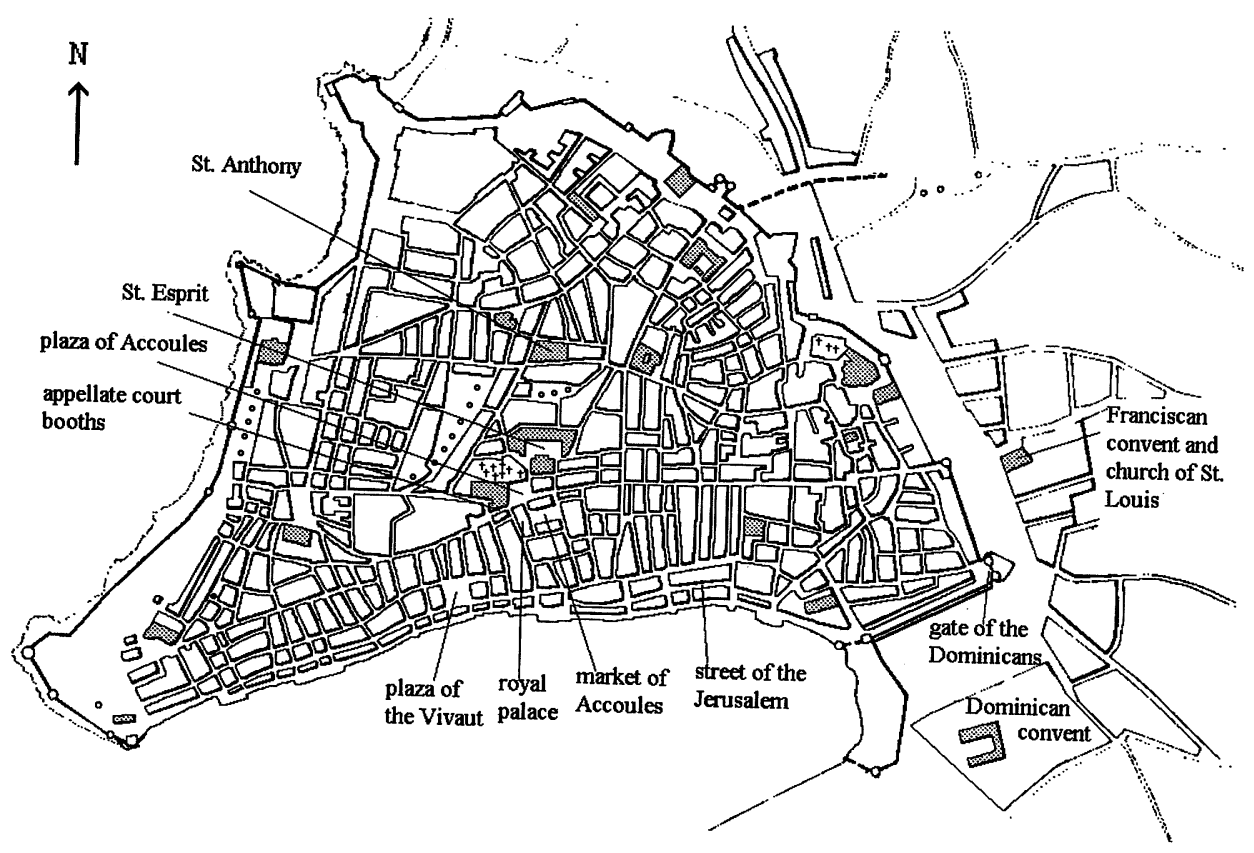

Figure 1 Marseille c. 1350.

of the appeal was reserved for the witness depositions, as each witness was asked to respond in turn to each of the titles, saying all that he or she knew that was pertinent.

Unlike the inquisition, however, the audience in the appeal was not necessarily restricted to the judge of the appellate court. We should, in fact, be wary of ever assuming that judges or juries are the sole audiences for any defense: defendants, even those who lose, can always benefit from a sympathetic public hearing. In Angevin Marseille, this appeal to a wider audience was promoted by the space in which the appeal was heard: like the courts for civil suits, the appeals court convened its sessions outdoors, in booths located in the plaza of Accoules, just beneath the lower door of the great parish church of Notre Dame des Accoules. Ringed by the church, the Hospital of St. Esprit, where the city council sat in session, and the royal curia, near one of the city's major markets, the plaza of Accoules was the heart of the city. It was a place where religion, authority, commerce, and justice intermingled, where all manner of citizens could be found. To understand the nature of the stories told during the appeal, it is important to understand that the stories may have had that larger public audience, that those who 
recruited the storytellers may have been concerned as much to impress the court of public opinion as they were to impress the judge.

\section{Telling Histories}

As dusk fell on the evening of 22 July 1351, the feast of St. Mary Magdalene, a group of men gathered in the plaza of the Vivaut to discuss the terms of a peace accord. Relations between the factions had been tense for the past week or two, to the point that several Vivaut allies and clients had prudently abandoned their homes located in the street of the Jerusalem, moving toward the comparative safety of the plaza of the Vivaut. ${ }^{35}$ Sporadic clashes between the rivals had punctuated the day: a Vivaut client, walking through the Cobblers' Quarter, had been attacked suddenly by a sword-wielding minion of the Jerusalem party; another Vivaut ally lay wounded in a nearby house. Full of wrath, anticipating violence, armed Vivaut allies and clients from all over the city gathered in the plaza and milled about, talking among themselves and watching the peace discussions unfold. Some were sleeping in the houses that ringed the plaza, their arms near at hand.

Suddenly a woman cried out, "Behold the enemies!" 36 for word had come that a host of armed men, between forty and one hundred fifty men in number, was marching toward the plaza of the Vivaut, headed by Peire de Jerusalem and another Jerusalem party captain, Isnart Eguesier. Hastily grabbing arms, Vivaut adherents poured out of the houses surrounding the plaza and hurried off eastward, down the street of the Vivaut, to confront the enemy. A scuffle ensued two blocks east of the plaza, at the foot of the street of the Massa: swords were drawn and blows delivered. The leaders, according to their own testimony, asked those fighting to retire peaceably, whereupon members of the Vivaut party returned to their houses. On the narrow streets of the city some of these men never even saw the enemy.

The violence was curiously restrained, the result less than bloody, but the potential for greater warfare seemed to horrify city leaders. Over the next few days, practically every figure of importance in the city administration joined with the parties to hammer out the peace accord; a formal instrument of peace, following a standard notarial protocol, was drawn up on 26 July 1351. Yet in September, the court of inquisition

35 Ibid., fol. $25^{\mathrm{v}}$ : ipse loquens ante per [?] certos dies mutuasset se de carreria de Jerusalem in qua est suam hospicium proprium in domo quadam Jacobi Sialhe.

36 Ibid., fol. $27^{\mathrm{r}}$. Asked by the judge who had called out, "Ecce inimicos!" the witness Laugier de Soliers reported that it was a woman [quadam mulier de qua suum nomen non recordatur]. 
decided to prosecute the parties for a series of lesser charges, primarily bearing arms within the city walls and making illicit congregations. By the late autumn, a sentence had been passed down: the leaders of the Vivaut and Martin party, twenty-four in all, were each fined between one hundred and two hundred pounds for their involvement in the fighting. The fines were collectively appealed a few months later. ${ }^{37}$

Filling eighty-five folios of one court register, the appeal they lodged is one of the longest cases extant from mid-fourteenth-century Marseille.$^{38}$ Like most appeals, it includes a transcript of the original judicial inquiry. The transcript takes up twenty-three folios of the appellate record and includes the testimony of at least twenty-four defendants from the Vivaut faction. Part of the original transcript has been lost - what fraction we do not know-for following a cover sheet entitled De parte Vivaudorum, testimony begins abruptly, in midstream. Absent are the list of charges and other preliminary materials that we would expect to find. The subsequent appeal was supported by the testimony of seventeen witnesses, including numerous men sympathetic to the Vivaut who had not been involved in the fighting.

Marseille's palace judge and therefore the head of the court of inquisition in 1351 was Johan Symeon. His inquiry, conforming to Roman legal procedure, consisted of a series of depositions from each of the accused. Johan or one of the assisting judges asked each defendant a series of questions pertaining to four basic titles. At times he interrupted a witness to probe more deeply into a point.

A transcript of a typical deposition, that of the Vivaut client Johan Aycart, follows. Unfortunately, the four inquisitorial accusations to which Johan was responding have been lost. Elsewhere we can get a sense of the general charge: a letter regarding several men who were claiming clerical immunity from prosecution speaks about accusations of "battle muster and bearing of arms as well as league and conspiracy in Marseille." ${ }^{39}$ From the testimony itself, we can infer that the first accusation was one of gathering illicitly. The third at least included and may have been exclusively the accusation of bearing weapons and causing wounds, and the fourth was the accusation of peacebreaking. Witnesses consistently responded to the second accusation with nichil scire ("knows nothing") throughout the inquisition transcript.

37 The documents do not say whether the Jerusalem were fined as well.

38 Ibid., fols. $15^{\mathrm{r}}-101^{\mathrm{v}}$.

39 Ibid., fol. $43^{r}$ : super congregatione rixe et armorum portatione nec non et super manipolio [ $s i c$ ] rassaque in civitate Massilie factis et habitis inter partes Vivaudorum et Jerusalem. 
On the same day [28 September 1351], Johan Aycart, one of the condemned men against whom the inquisition is being made, swore to abide by the order of the court and to tell the truth regarding the first accusation of the inquisition. It was diligently read and explained to him in the vulgar. As a principal concerning his own deeds and as a witness to those of others, he wholly denied the truth of every accusation made against him and, as a witness, said that he knew nothing. Asked if he had ever joined an illicit gathering either within the city of Marseille or outside, he said no. Asked if he knew or had heard it said that the party of Johan Vivaut had congregated without license from the court, he said no.

On the second accusation ...., he said he knew nothing.

On the third accusation ... he said it was true that the quarrel [insultus] took place on the day described in the accusation. He also said that several days earlier he, the witness, had moved from the street of the Jerusalem, in which his own house was located, to a house belonging to Jacme Sialhe, a house given to him by Jacme out of fear of the Jerusalem party. On the day of the quarrel, the speaker heard the cry, "To arms! to arms! behold the enemies!" namely those of the Jerusalem faction [illos de Jerusalem], and he seized his arms, namely breastplate, helmet, shield, and swordno other arms, or so he claims. He hurried to the place under the Arches of the Change, and there he found the party of the Jerusalem along with Johan Martin, ${ }^{40}$ Primar the procurator, and certain others whom he does not remember. Asked who, of the party of Peire de Jerusalem, were threatening them [irruerunt contra eos], ${ }^{41}$ he said Isnart Eguesier together with his servants. Asked by what names the servants went, he said Guilhem Verdelhon and someone from Aix with the Novel surname [de cognomine Novellorum]. He said there were around sixty men but because they were armed he could not recognize them. Asked if they struck any blow, the witness said the man from Aix named Novel tried to skewer him and struck his shield many times with his sword. Primar the procurator also struck out at the said men. Asked if he had wounded anyone in the battle, he said no, explaining however that the other party did strike many blows against the witness and others of his party. Asked with what intention and in what state of mind [qua intentione et animo] he had gone to the fight, he said with the aim of bringing back those of the Vivaut party, and he said that afterward each drew back to his own house. Asked if any among the Vivaut or Martin party were armed, he said yes, Johan Vivaut was armed, Uguo Vivaut, Jacme and Johan Martin, Peire Martin of the street of the Jerusalem, Carle Athos, Lois Athos, the other Lois Athos, Laugier de Soliers, lord Guil-

40 A major Vivaut ally, as was Primar Mirapeis, the procurator. The expression una cum inadvertently implies that Johan and Primar were allied with the party of Peire de Jerusalem.

41 This could be construed as "invading." The verb irruo has the sense of rushing out or rushing against. 
hem de Montoliu, ${ }^{42}$ Amiel Bonafos, Raymon de Laureis, Johan de Laureis - although he was carrying a helmet-Peire Amat, Peire de Lingris, Johan Naulon, Jacme Bonafos, Guilhem and Bernat Martin, Raymon Audebert, the notary, Johan Cayrellier, Bernat de Batut, Bertomieu Bonvin, Lois Bonvin-but he doesn't know if he was armed-and Guilhem Mersier, Uguo Ode, Johan de Strelhe, Guilhem de Temple of the Tanners' Quarter, Esteve de Brandis, Johan Fustier. All were armed with a variety of weapons that he does not recollect. Asked if any of them struck any blow in the battle, he said that he doesn't know. Asked many other questions, he said he knew nothing more excepting that to which he has testified. His memory coming back to him, he said that he struck out [cecidit] ${ }^{43}$ and was smitten by numerous sword strokes; he doesn't know who did it except that he heard it said that the same Novel tried to split his head [ fuit conatus sibi sindere capud]. More he says he does not know.

On the fourth accusation ... , he said he knew nothing.

Several features of the testimony stand out. First, the action was restricted to the space of several minutes. The only exception was the claim that the witness had left the street of the Jerusalem and moved to the plaza of the Vivaut several days before the battle. The bulk of the recorded testimony, made in response to the third accusation, was limited to the space of a few minutes, from the initial cry and the surge outward from the plaza of the Vivaut to the retreat of the Vivaut party members to their homes.

The testimony-or at least the part of it that was recorded-was therefore dominated not by the story of the events, but by the lists of weapons, names, and (to a lesser extent) the blows that fill the response to the third accusation. The list of proscribed weapons provided the judge with an easy way to fine the troublemakers; by keeping careful track of defensive and offensive arms, moreover, the judge could more readily assess the pleas of self-defense and peacefulness that this defendant, like others, managed to work into his testimony. The list of names was doubly useful: not only could the judge keep track of the participants, but he could also check the list against the list of the people who had committed themselves to the peace accord of 24 March 1350, thereby knowing whom he should fine more severely.

That way of asking questions had the effect of slicing the events up into discrete and disjointed frames. As one reads through the sub-

42 The word miles was written in superscript after the name and was probably added as an afterthought by the notary so that this Guilhem should not be confused with the jurist Guilhem de Montoliu, who at that very moment was serving as one of the lesser inquisition judges.

43 Cecidit would normally mean "murdered." Why the notary used this word (there is no other evidence suggesting that anyone died in this battle) is a mystery, as is the active voice, when to this point the witness has consistently presented himself as being passive. 
sequent depositions, one is inundated by a mass of disjointed and repetitive information. It is very hard to pull a story out of the lists. That may have been a deliberate tactic by the judge of the inquisition, for it served two convenient ends. First, it enabled the judge to focus testimony on infractions that were easily proven, such as bearing arms. Second, it distracted attention away from the long-term grievances that led up to the conflict. By so doing, the rhetoric of prosecution managed to avoid any reference to the larger and nastier political context.

In their original depositions, the Vivaut defendants, clearly constrained by the rhetorical framework used by the judge, were unable to fashion a convincing storyline. In response to the disjointed questioning, they could only portray themselves as men of peace. Asked why he became involved in the battle, the defendant Amiel Bonafos claimed that when he heard a warning cry he seized his weapons, rushed out to the plaza in front of his house, and asked his allies to return homeas they did, although the scribe added a skeptical ut dicit after this passage. ${ }^{44}$ Johan Aycart, as we have seen, admitted that he tried to strike someone but failed, suffering multiple blows in return; asked why he had gone to the battle, he echoed Amiel in saying that he intended to call back the members of the Vivaut party. ${ }^{45}$ When a third defendant was asked whether the members of the faction began fighting immediately after rushing out onto the plaza, he answered, "No, because Johan Vivaut [the eponymous leader of the faction] did not wish the plaza of the Vivaut to be torn up." 46

The tale changes when we turn from the witness depositions in the inquisition trial to testimony heard in the appeal, which opened in December 1351. The appeal was directed by the jurist Primar Mirapeis, a friend and ally of the Vivaut party. The defense he constructed by no means abandoned the claim of self-defense. With the twenty-fifth and the twenty-eighth of the thirty-one titles, Primar claimed that the Jerusalem had invaded the territory assigned to the Vivaut by a previous judge; ${ }^{47}$ the twenty-seventh title argued that the men who gathered in the plaza of the Vivaut bore only defensive arms. ${ }^{48}$ Nor did Primar

44 Ibid., fol. $24^{\mathrm{v}}$ : accessit usque ad carreria causa dicendi gentibus de parte Vivaudorum et Martinentorum quod recederent ad domos suas et sic, ut dicit, recessit quilibet ad domum suam.

45 Ibid., fol. $26^{r}$ : que intentione et animo ibat ad dictum conflictum . . . animo reducendi illos de parte Vivaudorum.

46 Ibid., fol. $27^{\mathrm{r}}$ : Interrogatus si aliquos ibi lansavit ictus dixit quod non quod Johannes Vivaudi noluit ... quod platea Vivaudorum non dirrueretur etiam noluit dictus Guillelmus de Monteolivo miles.

47 As one witness (ibid., fol. $86^{\mathrm{r}}$ ) explained, "territories were assigned by the court to each party" [confines erant per curiam assignate utrique parti]. See also fols. $59^{\mathrm{v}}, 67^{\mathrm{v}}, 71^{\mathrm{r}}$.

$48 \mathrm{See}$, for example, the testimony of one of the defendants, Montoliu de Montoliu, who claimed (ibid., fol. $68^{\mathrm{r}}$ ) that the arms borne by the Vivaut (breastplates and corselets) were used 
shrink from a defense based on procedures: the judge of the inquisition, for example, was formally incompetent to serve, having been elected to office by a committee that included an excommunicate (the city councilor Peire Desdier). Titles one through sixteen and eleven of the seventeen witnesses were devoted to such procedural issues, and testimony on those takes up the bulk of the depositions.

But the gripping passages of the appeal center on histories of the hatred, outlined in titles eighteen through twenty-four. In a series of depositions, we hear stories about Jerusalem iniquities. One day, for example, Peire de Jerusalem and his henchmen invaded the church of the Franciscans during the middle of mass, had words with a Vivaut ally named Johan Martin, and then attacked Johan and his friends, wounding Johan de Laureis. ${ }^{49}$ We learn too about the recent killing of Guilhem and Johan Mercier at the hands of Jerusalem allies named the Serviers..$^{50}$ We learn of the wounding of yet other Vivaut allies, Olivier Bonpar and Nicolau Baudron, ${ }^{51}$ and the murder of Guilhem Bonpar. A past notary of the inquisition, Uguo de Gemenos, was brought in to testify to what he remembered from past trials; he was able to report the murder of two fishermen, minor clients of the Vivaut. ${ }^{52}$ Several witnesses described the murder of a man named Baxonetus. ${ }^{53}$ In several depositions we learn about the militia or "armed band of servants" [sequelam hominium armatorum] supported by Peire de Jerusalem and are told of his effrontery in threatening Vivaut allies in their. own homes. ${ }^{54}$ Six witnesses were brought to attest to these tales, telling and retelling more or less the same list of Jerusalem crimes.

Two of the six witnesses tell us directly about the historical depth of the hatred between the Vivaut and the Jerusalem. The twenty-yearold nobleman Montoliu de Montoliu had heard that the "dispute between the Vivaut and the Jerusalem was ancient" [quod antiquitus fuit rumor inter Vivaudos et illos de Jerusalem]. ${ }^{55}$ The merchant Laurent Rostahn, at the somewhat riper age of thirty-six, observed that those in "the party of Peire de Jerusalem . . . have always had a great hatred for those of the Vivaut party." ${ }^{56}$ Responding to the penultimate title-

\footnotetext{
"for their defense, not for attacking anyone" [pro deffentionem ipsorum et non ad offentionem cuiuscumque].

49 Ibid., fols. $59^{\mathrm{r}}, 62^{\mathrm{v}}, 67^{\mathrm{r}}, 85^{\mathrm{v}}$.

50 Ibid., fols. $63^{\mathrm{r}}, 67^{\mathrm{v}}, 85^{\mathrm{v}}$.

51 Ibid., fols. $67^{\mathrm{r}}, 81^{\mathrm{r}}, 85^{\mathrm{r}}$.

52 Ibid., fol. $87^{\mathrm{v}}$.

53 Ibid., fols. $63^{\mathrm{r}}, 70^{\mathrm{v}}$.

54 Ibid., fols. $58^{\mathrm{v}}, 67^{\mathrm{r}}, 85^{\mathrm{v}}, 87^{\mathrm{v}}$ (militia); $67^{\mathrm{r}}, 70^{\mathrm{v}}$ (threats).

55 Ibid., fol. $66^{\mathrm{v}}$.

56 Ibid., fol. $70^{\mathrm{v}}$ : aliqui de parte Petri de Jerusalem interfesserunt Bacxinetum et semper habuerunt magnam inimicitiam contra illos de parte Vivaudorum.
} 
that these are commonly known facts-Laurent noted drily, "It is common knowledge in the city that these parties have disputes and battles among themselves." ${ }^{57}$

Significantly, none of the six witnesses testifying to past events was a known Vivaut party adherent. That was probably deliberate: in that way, the history could be presented as impartial public knowledge. Two-Johan Thame and Uguo de Gemenos-were notaries with no connection to either party. ${ }^{58}$ The remaining four witnesses, in addition to Montoliu de Montoliu and Laurent Rostahn, included the merchant Johan Johan and the nobleman Ricau Ricau. Of these four, all but one had ties of marriage and/or blood to both factions. Like all witnesses, Johan Johan, for example, was asked by the judge "if he was related to either party in the case" [interrogatus si atinet alicui homini dictarum partium in aliquo gradu consanguinitatis vel affinitatis]. He answered yes: to Jacme Martin (of the Vivaut party) by marriage; to Borgonho Borgonho of the Jerusalem party in the third degree ("vulgarly called a second cousin" [coyn segon]); to Jorge Guigo and Jacme Bertran of the Jerusalem party in the fourth grade; and to Bertran Johan of the Jerusalem party by marriage. ${ }^{59}$ Ricau Ricau was the exception, related only to the Martin family. In theory, this group of witnesses offered the most objective testimony possible.

The point of the stories they were recruited to tell is clear: any violence committed by the Vivaut was a logical response to past Jerusalem outrages. Over the next five years, the occasions for this kind of storytelling grew. The low point in the feud came five years after the battle of 1351, on or shortly before 12 May 1356, when an unarmed Peire de Jerusalem was murdered by Amiel Bonafos-an important figure related by marriage to both the Vivaut and the Martin lineages-and other members of the Vivaut party. The victim had been on his way to the church of St. Louis in the Franciscan convent in the suburbs. Just outside the first gate he was ambushed by his enemies and stabbed in twenty-two places. At least five of the ringleaders - the three Martin brothers, along with Amiel Bonafos and Girart de Buco-were subsequently tried and fined huge sums ranging from two thousand to seven thousand pounds. ${ }^{60}$ All five appealed their fines beginning in July 1356,

57 Ibid., fol. $71^{\mathrm{r}}$ : publica vox et fama est in civitate predicte quod predictas partes rumores et brigas insimul habuerunt.

58 Public notaries in the Middle Ages frequently wrote chronicles and histories. In a sense, their authoritative knowledge (because documented) about past contracts merged indistinctly into their authoritative knowledge about past events.

59 Ibid., fol. $63^{\mathrm{v}}$.

60 Huge sums indeed. The largest dowry from the period was one thousand pounds, the average closer to two hundred. Houses rarely cost more than one hundred pounds. The largest 
Table 1 The History of Jerusalem Crimes, as Told by the Vivaut (c. 1309 to 1356 )

\begin{tabular}{|c|c|}
\hline 1309 & the extraction of the eye of Peire de Bellaygris \\
\hline 1331 & wounding of the subvicar, the lord of Capriers \\
\hline 1336 & murder of Franses de Hostia \\
\hline before July 1351 & wounding of Johan de Laureis in the church of the Franciscans \\
\hline before July 1351 & $\begin{array}{l}\text { eviction of Johan and Jacme Martin from the street of the } \\
\text { Jerusalem }\end{array}$ \\
\hline before July 1351 & murder of Guilhem and Johan Mercier \\
\hline efore July 1351 & wounding of Nicolau Baudron and Olivier Bonpar \\
\hline efore July 1351 & murder of Guilhem Bonpar \\
\hline before July 1351 & $\begin{array}{l}\text { brawl involving Peire de Jerusalem, Marques de Jerusalem, Peire } \\
\text { Carbonel, and associates with the sons of Guilhem Mercier }\end{array}$ \\
\hline before July 1351 & murder of two fishermen associated with the Vivaut party \\
\hline 22 July 1351 & $\begin{array}{l}\text { battle of } 1351 \text { (described as a Jerusalem invasion of the plaza of } \\
\text { the Vivaut) }\end{array}$ \\
\hline May? 1355 & $\begin{array}{l}\text { attempted assassination of the subvicar, Peire Guibert, and } \\
\text { wounding of Feraut de Barras }\end{array}$ \\
\hline before $\mathrm{N}$ & assault on two servants of Girart de Buco \\
\hline before May 1356 & attempted assassination of Johan Casse \\
\hline before May 1356 & Jerusalem depredations in the countryside \\
\hline before May 1356 & $\begin{array}{l}\text { wounding of the servant of the knight Guilhem de Montoliu and } \\
\text { of an unknown man of the Bonpar family }\end{array}$ \\
\hline May 1356 & $\begin{array}{l}\text { attempted murder of Amiel Bonafos in the neighborhood of } \\
\text { Cavallione }\end{array}$ \\
\hline May 1356 & wounding of Laugier de Soliers and of Guilhem Martin \\
\hline
\end{tabular}

Sources: ADBR, IIIB 811, 812, 819, 820.

although the appeal lodged by the Martin brothers was temporarily quashed on a technicality. ${ }^{61}$

In the appeal of Amiel Bonafos, similar in size and structure to the one that followed the battle of 1351, the history of the feud was presented with even more historical depth and rigor, as twenty-five witnesses were brought to attest to seventeen titles, six of which were devoted to Jerusalem iniquities ${ }^{62}$ New stories emerge in those appeals: given the interval of time, the list of Jerusalem iniquities had grown. From those two appeals, along with that of Girart de Buco, we can reconstruct the history outlined below.

personal fortune I have been able to uncover is that of Alexander Girart, who claimed in a court case that he was worth three thousand pounds; see ADBR, IIIB 812, case of Jacoba Augeleria, fol. $32^{\mathrm{v}}$.

61 Their appeals were lodged by their wives, and the judge pointed out immediately that wives cannot represent husbands in such cases.

62 ADBR, IIIB 820 , fols. $8^{\mathrm{r}}-103^{\mathrm{v}}$. Girart de Buco's appeal, although similar in size and structure to Amiel's, is heavily damaged by water-staining and difficult to use. 
This history begins around the year 1310, the date of the earliest Jerusalem outrage documented, as it were, by Amiel Bonafos. His informant was the ancient lady Boneta Sarda. "Forty-six or forty-seven years ago," she explained,

Peire and Uguo de Jerusalem and many others of their party, during a battle that was taking place between the party and lineage [inter partem et genus] of the witness herself on the one hand and the Jerusalem on the other - a man named Peire de Bellaygris fled from them into the cathedral church of BM Sedis Massilie to the altar; they wounded him in the face, gouging out an eye. Everyone knew it. ${ }^{63}$

It was also Boneta who related the next incident, the wounding of the subvicar, the lord of Capriers, around the year 1331. She was then living in the house of a relative, Bertrana Sarda, underneath the royal palace. She heard a quarrel in the street and saw the lord of Capriers wounded in the forehead; brought into a nearby house where she was present, he told those present that Uguo and Peire de Jerusalem had done it. ${ }^{64}$

Her stories, corroborated in part by an old man, Peire Bausan, who had preceded her, helped establish that the grievances were not restricted to the Vivaut and perhaps their immediate allies. About a third of the witnesses recruited by Amiel, in fact, were not obviously members of the Vivaut party. As in the earlier appeal, the seeming impartiality of the witnesses contributed to the verisimilitude of the tales they told, illustrating the public nature of the facts. The point being made was obvious: These were not private stories shared around the hearth in miserly fashion. They were public histories, known to all Massiliotes. "Ten, twenty, thirty, forty people say these things," claimed the Vivaut ally and witness for Amiel, Primar Mirapeis. ${ }^{65}$

Subsequent tales told by numerous witnesses served to bring the record up to date, filling in the years between 1351 and 1356 and adding one or two other flourishes, such as the assault on Franses de Hostia. It is unlikely that those witnesses were as unstained by links to the Vivaut as they would have had the judge believe. That is precisely the point made by an official of the court, called the clavarius or "clavaire," delegated to defend the original condemnation once the appeal had been completed. Although curiously unable to impugn Boneta Sarda, this official did point out that Peire Bausan and many other witnesses, seventeen in all, were biased toward the Vivaut ${ }^{66}$ But the very act of

63 Ibid., fol. $78^{v}$. The key phrase is "ante altara ipsius ecclesie vulneraverunt in facie ... unum oculum sibi extraxerunt."

64 Ibid., fol. $78^{v}$.

65 Ibid., fol. $69^{\mathrm{r}}$.

66 Ibid., fol. $90^{\mathrm{r}}$. 
testifying or even spreading rumors against one party was fraught with danger and seems to have been punished quite severely by the opposing party. Franses de Hostia, for example, lost his life owing to his imprudent tongue ${ }^{67}$ and eye-gouging, as suffered by Peire de Bellaygris at the hands of the Jerusalem, was a common reprisal for hostile testimony. ${ }^{68}$ Whatever their prior stance toward the party that had recruited their testimony, witnesses, especially those with little power, were probably drawn into the party orbit once their words became public.

One hint that the tales were at least to some extent orchestrated by the Vivaut emerges from the repetitive quality of the testimony. The tale of Johan Casse, for example, crops up in eleven separate depositions in this appeal. Suspected of the murder of Marques de Jerusalem, Johan was being carried off by the vicar, the subvicar, and the servants of the court for questioning. The little band of men was assailed on the way to the court by Vivaut and Pons de Jerusalem, Leo de Cepeda, Guilhem Naulon, Uguo de Serviers, and other Jerusalem allies. Seeing their drawn swords, Johan hid himself in a shop selling miscellaneous groceries (merces) and the subvicar, Peire Guibert, defended the door, saying gallantly, "You shall not have him unless I am dead first!" 69 Wounded in the head by Guilhem Naulon, Peire Guibert spat back, "You have wounded me, but you stink in your body." 70

The tales, of course, were clearly skewed toward the Vivaut to the extent that they rarely acknowledged Vivaut misdeeds. Tellingly, all Vivaut crimes were presented as natural reprisals. The battle of 1351, for example, was not only a response to the Jerusalem invasion of Vivaut territory; it was also the natural outcome of a series of murders and assaults in the months or weeks leading up to the battle. The murder of Peire de Jerusalem in 1356, in turn, was a response to the attempted assassination of Amiel Bonafos, to the assault on Johan Casse, and to a series of Jerusalem depredations in the countryside, as bands of armed men roamed the highways looking for Vivaut and Martin men to assassinate and seizing letters that might incriminate their enemies.

In the testimony, then, events were strung together into a sequence, with one act of vengeance following upon another. That is a key point, for this act of making a history took the isolated events of the past, knowledge of which circulated widely in the city, and built them into an ordered chronology. The chronology served as an excuse for

67 Ibid., fol. $76^{\mathrm{v}}$.

68 See Stephen Wilson's discussion of this in his Feuding, Conflict, and Banditry in NineteenthCentury Corsica (Cambridge, 1988).

69 ADBR, IIIB 820 , fol. $74^{\mathrm{r}}$. The tale was also told by ten other witnesses.

70 Ibid.: Vos vulnerastis me sed vos emetis de corpore. 
the actions of the defendants: in a heroic culture, revenge is inevitable and mechanical. It is an emotion or action that suppresses the will. The appeal to the logic of vengeance was not blatant in the appeals: vengeance was in sufficiently bad odor, among both ecclesiastics and secular judges in the mid-fourteenth century, to allow a more obvious appeal to the validity of vendetta. In the inquisition trial, after all, the defendants initially tried to develop a more conventional argument based on self-defense. But the appellate strategy is evident enough, to judge by the weight of testimony allotted to the questions and by the repetitious quality of the testimony. Thanks to the public arena in which appeals were heard, moreover, the stories could be publicized in their new historical clothing, accompanied by all the ritualistic elements of the judicial process, outside the social spheres in which they originally circulated. In that way, the court system, however much it may have hindered the untrammeled pursuit of blood, unwittingly contributed to an institutionalization, in the form of public histories, of the very hatreds it sought to suppress.

\section{Justice as Vengeance}

Hatreds were also institutionalized in the drama of the court itself. Spilling blood was pleasurable enough, but where it was constrained, avatars of violence could always seek vengeance in court. The appeal, allowing as it did the telling of stories, permitted one party to execute a kind of rhetorical vengeance.

Such vengeance was a delicate affair. Blood vengeance was portrayed as noble and heroic. Yet anyone could recognize that the tactic tended to place the parties on an equally honorable footing. The Vivaut, for instance, could avoid only with difficulty a serious problem in their arguments, namely that the very Jerusalem iniquities that were so upsetting to them were clearly, in many cases, ripostes to Vivaut assaults. To take but one example, the attempted assassination of the Vivaut ally Johan Casse was a very reasonable response, according to the logic of vengeance, to an earlier event, for Johan apparently had murdered Marques de Jerusalem. So witnesses characterized the violence of their enemies in such a way as to make it offensive to common social norms, and therefore, in some respects, uncivilized..$^{71}$

Vivaut witnesses, for example, liked to tell stories of how the Jerusalem scaled the walls of buildings to break in and murder their vic-

71 This is discussed in Edward Muir, Mad Blood Stirring: Vendetta and Factions in Friuli during the Renaissance (Baltimore, Md., 1993). 
tims, chanting, "Mora! Mora!" as they did so.72 They were described as "rabid" in their hatred of a Vivaut ally. ${ }^{73}$ Although this language has none of the bestial images conveyed by sixteenth-century Friulans, the animal overtones are unmistakable. The Jerusalem attacked people in their own houses. Worse, even the sanctuary of church and cathedral was breached on at least three occasions: one was the incident in the cathedral in 1309, where Peire de Bellaygris lost an eye; the second, the attack against Johan de Laureis in the Franciscan church before 1351; and the third, the assault on the church of St. Anthony, where Peire Guibert was hiding in the campanile, in 1355.

In the appeal of Amiel Bonafos, the defendant's civil-minded use of the courts stood in sharp contrast to Jerusalem abuse thereof. A great deal of testimony in this case revolved around the argument that in 1356 the Jerusalem had formed a secret conspiracy with the vicar, Raymon de Bariaco, to persecute the Vivaut party through extrajudicial means. ${ }^{74}$ That the vicar publicly favored the Jerusalem (title nine), reports the witness Esteve de Brandis, is commonly repeated "both by Christians and by Jews" [tam per christianos quam per judeos]. ${ }^{75}$ "Twothirds of the city say this," claims another witness, Uguo Vivaut, explaining further how he knows it to be true. First, members of his own party were more frequently incarcerated than those of the Jerusalem party. Second, the vicar, fearful of pursuing an inquisition against some Jerusalem allies (the Gili) in the face of popular opposition, chose to flee the city; and third, he had two lesser Vivaut clients "tortured in the absence of a judge" - in other words, gratuitously [fecit . . in eculeum elevari sine iudice]. In an earlier deposition, the great merchant Peire Austria supported these claims, suggesting that the Jerusalem so dominated the vicar that they could have their enemies tortured "on their own authority" [ad instanciam partis]; "the vicar had been corrupted by money" [dictus dominus vicarius fuit corruptus pecunia]. ${ }^{76}$

But this game could be played by both parties, and the tendency to impugn the enemy's motives is especially clear in tales told by the Jerusalem. Let us turn to the Jerusalem version of the history. It is a meager history, because the nine extant appeals lodged on behalf of Jerusa-

72 E.g., the testimony of Bernart de Tortoza, ADBR, IIIB 820 , fol. $76^{\mathrm{v}}$ : ascendentes per theguliciam et parietes intraverunt in domum ubi dictus scutifer erat et fuit dictus scutifer interfectus. See also the testimony of the notary Guilhem de Bellavila, fol. $56^{\mathrm{v}}$.

73 Ibid., fol. $56^{\mathrm{v}}$.

74 This argument was outlined in titles eight through ten, fourteen, and fifteen at the beginning of the appeal; see ibid., $46^{\mathrm{v}}-47^{\mathrm{r}}$.

75 Ibid., fol. $70^{\mathrm{r}}$.

76 Ibid., fols. $60^{\mathrm{r}-\mathrm{v}}$. 
Table 2 The History of Vivaut Crimes, as Told by the Jerusalem

\begin{tabular}{ll}
\hline Nov. 1351 & $\begin{array}{c}\text { assault on Isnart Eguesier and Peire Carbonel by the Vivaut captain } \\
\text { Amiel Bonafos and others } \\
\text { murder of Marques de Jerusalem; prime suspect was the merchant } \\
\text { Johan Casse }\end{array}$ \\
Sept. 1354 & $\begin{array}{l}\text { murder of Jerusalem client Jacme Bertran by the subvicar and Vivaut- } \\
\text { sympathizer Peire Guibert; pursuit of Peire Guibert by Jerusalem; } \\
\text { brawl outside St. Anthony } \\
\text { murder of Peire de Jerusalem by Amiel Bonafos and Martin brothers } \\
\text { shortly before May 13 }\end{array}$ \\
\hline
\end{tabular}

Sources: ADBR, IIIB 812, 819, 820.

lem party members are in all respects very thin..$^{77}$ To that, however, is added a much richer source, for the prosecution of the ringleaders in the murder of Peire de Jerusalem in 1356 technically took the form of a private suit, led by a cousin of the dead man named Johan de Jerusalem. From this material we can construct the following history.

The charge developed by Johan de Jerusalem in 1356 was a masterpiece of innuendo designed to shame Amiel and his colleagues. Johan's most conspicuous rhetorical device was the refusal to place the murder in any kind of feuding chronology that would allow it to be seen as a revenge. According to Johan,

The murderers had been gathering secretively and suspiciously, especially in a house called La Sala, just outside the gate of the Dominicans, which in common opinion is an underworld place and the home of thieves, murderers, and other evil doers. . . . The late Peire de Jerusalem was on his way to the church of St. Louis together with the other Peire de Jerusalem, his uncle, without any arms; emerging from that place called La Sala where they had been hiding secretively [the murderers] came upon the said Peire and ... clamoring "Death! Death!" against him, they struck various mortal wounds, twenty-two in all, on his person and limbs with quarrels, spears, swords, and arquebuses [chavarivii], from which wounds Peire immediately left this life.78

In this there is no hint that the murder was motivated by revenge. The assailants were associated with common murderers and thieves, and the judges and the audience were allowed to extract a motive from that.

77 See ADBR, IIIB 812, fols. $1^{\mathrm{r}}-22^{\mathrm{v}}$; ADBR, IIIB 813, fols. $92^{\mathrm{r}}-97^{\mathrm{r}}$; and ADBR, IIIB 819 (the entire register is devoted to seven minor appeals arising from the assault on Peire Guibert in 1355).

78 Ibid., fols. $12^{\mathrm{r}}-13^{\mathrm{r}}$. 
To illustrate the savagery of the assault, Johan brought in one Jewish and four Christian physicians to enumerate and describe for the court the nature of the wounds: a mortal wound on the head, another mortal wound caused by a quarrel on the right side of the body; a third, a deep incision, on the right knee; a fourth on the right foot, a fifth on the left arm, and so on. ${ }^{79}$

That savagery was bad enough. Their guilt was compounded by two other charges of greater subtlety. First, they broke all the rules of honor by assaulting an unarmed man and by being secretive. The conspiratorial quality of the event was heightened by the description of the events leading up to the murder:

Amiel Bonafos and Johan Martin and the others ... were plotting the murder outside the city of Marseille, both in Aubagne and in Toulon. ... Four or five days before the murder . . . , he [Amiel] slipped into Marseille secretly, wearing the habit of a monk [cum habitu monacali]..$^{80}$

Second, the pious victim was on his way to church-and not just any church, but the Franciscan church of St. Louis. Of all the religious orders of medieval Europe, the Franciscans were the most closely associated with peacemaking. The church's namesake, moreover, was the Angevin St. Louis, the centerpiece of the devotion that linked the city of Marseille to Naples. ${ }^{81}$ Johan de Jerusalem may therefore have been casting the murder of his cousin Peire as an affront not only to piety but also to the Angevins themselves. ${ }^{82}$

That the court was known to be a place in which vengeance could be pursued is indicated in testimony offered by a major Vivaut ally, the jurist Primar Mirapeis, during Amiel's defense in 1356. Primar observed that the Jerusalem persecuted Amiel out of capital hatred, odio capitali as the expression goes. Asked how he knew this, Primar responded that he had been present when the members of the Jerusalem party initiated the judicial inquiry against Amiel and when they later asked for a written copy of the subsequent condemnation. ${ }^{83}$ Active involvement in prosecution, apparently, was evidence enough for hatred

79 Ibid., fol. $41^{\mathrm{v}}$.

80 Ibid., fol. $28^{\mathrm{r}}$. 1954).

81 Marie Hyacinthe Laurent, Le Culte de saint Louis d'Anjou à Marseille au XIV siècle (Rome,

82 Given Peire de Jerusalem's assaults on Vivaut members attending mass in the church, of course, this charge was available to the other side as well.

83 ADBR, IIIB 820, fols. $68^{\mathrm{v}}-69^{\mathrm{r}}$ : Dixit quod pars dictorum de Jerusalem tempore quo processus factus contra dictum Amelium persequta fuit dictum Amelium, credens quod odio capitali. Interrogatus quomodo hoc scit, dixit quia vidit et presens fuit, quia vidit quando pars dictorum de Jerusalem obtulit titulos contra dictum Amelium et instrumentum petiit de dicta summa. 
in the eye of this jurist. Amiel himself claimed that the Jerusalem party was unjustly prosecuting him out of capital hatred. ${ }^{84}$

That argument shows up elsewhere in court cases from the period. It is a curious claim. Does one ever prosecute out of affection? Nonetheless, it reveals well the sense that the courts were being used for something other than what defendants imagined they should be used for, to develop hatreds rather than resolve them. ${ }^{85}$ The implication seems clear: it is dishonorable to get the court to do your dirty work. If vengeance is to be taken, it should be pursued outside the court: a maxim, of course, honored chiefly in the breach.

\section{A Language of Membership}

Hatreds, as we have seen, were as much institutionalized as they were repressed by court intervention in mid-fourteenth-century Marseille. First, the appellate process helped people create and make formal their histories and therefore identities, serving, if not to create, at least to affirm group identity, helping to solidify the sense of a common grievance. Second, the court itself was a place for the pursuit of vengeance, not its repression. The experience of prosecution helped crystallize factional identity in a third way, namely by providing a language of group membership and by encouraging witnesses and defendants to identify themselves, publicly, with one party or another.

The judges in these cases liked to think in simple, clear terms. They liked to deal with factions that had names. These were the pars Vivaudorum, sometimes the pars Vivaudorum et Martinentorum, and the pars de Jerusalem. The feud itself had a name: it was a great hatred, a magnam inimicitiam inter partem Vivaudi et partem de Jerusalem, or a magna discordia et guerra. It was identified with given regions of the city, the Vivaut with the plaza that bore their name, the Jerusalem with their own street. Judges even assigned territories or boundaries (confines) ${ }^{86}$ to each party during the worst of the fighting. The Vivaut's boundary, for example, ran down the street of the Massa, ${ }^{87}$ to the corner, also called "the corner of the heirs of Guilhem Tomas, where their boundaries are [i.e., the Vivaut's]," 88 or "the corner of the street of Guilhem de Alans,

84 Ibid., fol. $47^{\mathrm{r}}$. The actual word used was prosequitur, from prosequor, "to attack" or "to pursue," the root of our verb "to prosecute."

85 A very similar point is made in Stephen D. White, "Proposing the Ordeal and Avoiding It," in Cultures of Power: Lordship, Status, and Process in Twelfth-Century Europe, ed. Thomas N. Bisson (Philadelphia, 1995). My thanks to a reader for drawing this to my attention.

86 See above, n. 47.

87 ADBR, IIIB 811 , fols. $27^{\mathrm{r}}, 28^{\mathrm{v}}, 39^{\mathrm{r}}$.

88 Ibid., fol. $32^{\mathrm{v}}$ : ad dictum locum cantoni heredum Guillelmi Thomacii ubi erant eorum confinie. See also fol. $30^{\mathrm{v}}$. 


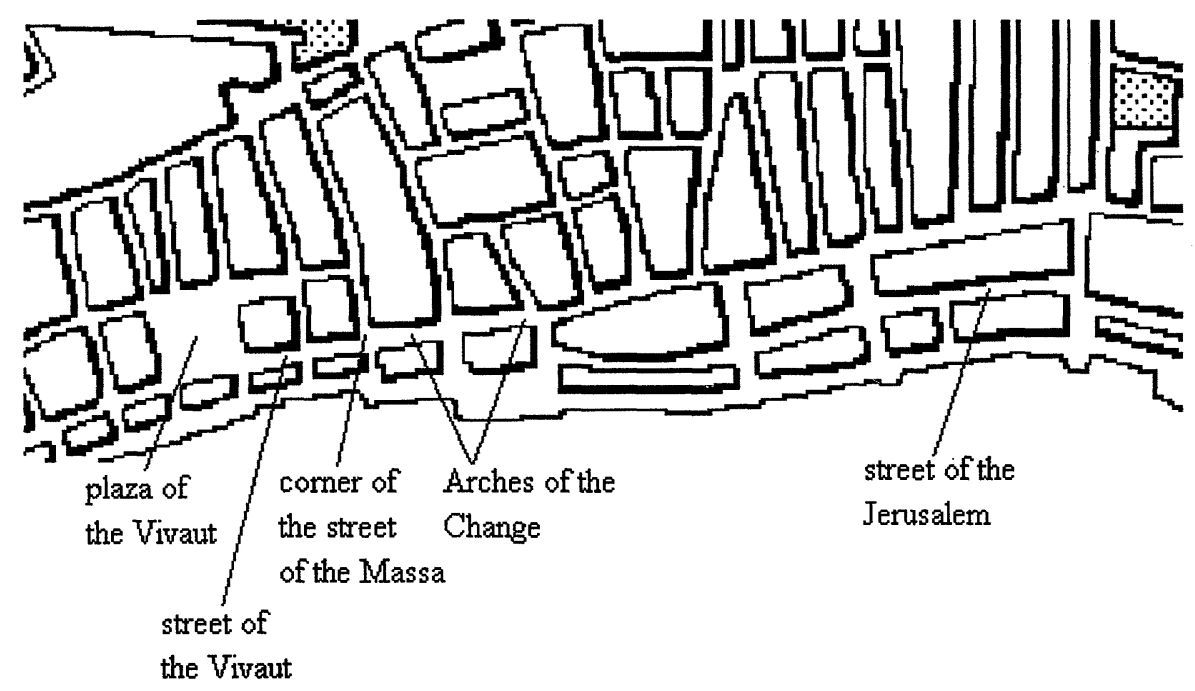

Figure 2 The Axis of Hatred: Geography of the Battle of 1351.

within their boundaries." ${ }^{89}$ Peire de Jerusalem and his band of men had come as far as the nearby areas known as the Arches of the Change, "where purses are sold," thereby threatening the Vivaut territory. ${ }^{90}$

Judges also liked to think that the factions had readily identifiable memberships. Although presented as groups of agnates - the Vivaut, the Martin, the Jerusalem - the factions were more than just the members of two or three lineages, for it is clear that agnatic kinship played only a modest role in recruitment. To describe the relationships, the court notaries used a language of membership. This language distinguished between allies, or social equals, and inferior clients of each of the party leaders.

Horizontally, the party leaders recruited members primarily through marriage and friendship. They were given a variety of names: friends (amicos), associates (socios, consocios), allies (complices), partisans ( fautores, fatares), adherents (adherentes). Thus, in the peace instrument of 26 July 1351 - an act supervised by leading city officials, including the vicar and probably the palace judge - the anonymous author spoke of a "great enmity and state of warfare between the nobleman Peire de Jerusalem and his friends, allies, and co-conspirators on the one hand, and Johan Vivaut and his friends, allies, and co-conspirators on the

89 Ibid., fol. $34^{\mathrm{r}}$ : ad cantonum carreria Guillelmi de Alanis infra confinias suas.

90 Ibid., fol. $68^{\text {r }}$ : illi de parte Petri de Jerusalem egressi fuerunt usque ad locum Crotarum ubi marsupia venduntur eundo versus partem Vivaudorum et Martinentorum. 
other" [magna discordia atque guerra in civitate Massilie inter nobiles Petrum de Jerusalem et suos amicos complices et fatares ex una parte et Johannem Vivaudi ac suos amicos complices et fatares ex altera]. ${ }^{91}$ Several passages speak of captains or leaders: Amiel Bonafos, for example, was described at one point as "belonging to the Vivaut and Martin party and one of the captains thereof" [Amelius Bonifacii fuit et est de parte Vivaudorum et Martinenquorum et unus ex capinibus eorundum].$^{92}$

A great deal of fighting was done, of course, by what we might call clients. Those men, of ordinary backgrounds-laborers, fishermen, mariners, tanners, and so on - were often called domestici, familiari, or familii (sing. famulus, familius) in the sources, but "servant" is a poor translation, since many of them were not household servants: they pursued their own trades or crafts and lived apart from their patrons. Genuine servants were sometimes called domestici as well, but were more commonly described as being "of the servant-body of so-and-so" (de familia sua). An armed servant of a nobleman was called a shield-bearer or squire (scutifer); Isnart Eguesier, for example, was frequently accompanied by his squire, Guilhem Verdelhon. The life of a household servant, apparently, shaded off into party membership quite easily: two female servants of Amiel Bonafos who testified on his behalf in 1356, Covenenta Raymbauda and Sibilia Pinhola, had sons and husbands in the Vivaut party and were in some ways considered members themselves. ${ }^{93}$ As one witness put it, Covenenta Raymbauda "always praised the Martin party and Amiel's party" [semper laudabat partem Martinentorum et partem Amelii], and a second witness said that Covenenta and her son Antoni were "both of the Vivaut party" [sunt de parte Vivaudorum]. ${ }^{94}$

The adjuncts, allies and clients alike, were not mere pawns in the greater hatred. Many had their own hatreds to pursue. We hear frequently, for example, of the great hatred between the wealthy but upstart Martin lineage and the Jerusalem, a hatred that pressed the Martin into an alliance with the Vivaut so firm that the two were sometimes named as one, the pars Martinentorum et Vivaudorum; in certain cases, in fact, the pars Martinentorum wholly supplanted the pars Vivaudorum in judicial onomastic. The Servier and the Mercier were implacable enemies, layering their own enmity over the Vivaut-Jerusalem axis the better to revenge themselves on the other. Minor clients, like the Englese and the Toesco families, both fisherfolk, swelled the ranks of each faction and added their own often documented hatred in so doing. So

91 ADBR, IIIB 820, fol. $18^{\mathrm{v}}$.

92 Ibid., fol. $90^{\mathrm{r}}$.

93 Ibid., fol. $90^{\mathrm{r}}$.

94 Ibid., fol. $93^{\mathrm{v}}$ (testimony by Guilhem de Matis) and fol. $94^{\mathrm{r}}$ (testimony by Antoni Deodat). 
numerous were the allies and clients that they threatened to swamp the agnatic cores of the Vivaut and the Jerusalem. Of 137 men associated in some way with the Vivaut party in the mid-fourteenth century, only three bore the Vivaut surname - that despite the fifteen or twenty Vivaut men known to have lived in the city at the time. Similarly, the flourishing Jerusalem lineage boasted between thirty and forty men; only three or four actively participated in the feud, either in fighting or in other expressions of support, such as courtroom assistance. ${ }^{95}$

These, then, were large and ungainly groups. Nonetheless, the courts liked to think they could construct long lists of members. The inquisition arising from the battle of 1351 had a list with twenty-four names. The two extant peace instruments all had somewhat shorter lists of names of party members, between three and ten in all on each side. And in 1356, Johan de Jerusalem helpfully listed the men who participated in the murder of Peire de Jerusalem in several places; a composite list bears thirty-three names. The very idea of such lists was fostered by the language of membership.

It is difficult to say, of course, where that language comes from. The notaries, who wrote in Latin, may have been transcribing Provençal words used consistently to describe members. They may also, unconsciously, have been layering their own interpretations on looser usages. But whatever the case, it is clear that membership was a great deal more volatile than judges liked to think. Some people, like Johan and Guilhem Vivaut, along with Amiel Bonafos and the Martin brothers, were always near the heart of things. Yet, of the twenty-four Vivaut allies and clients (the better documented of the two parties) condemned for the battle of 1351, only seven show up on the list of thirty-three people accused of the conspiracy to murder Peire de Jerusalem in 1356. A small battle that took place on 17 November 1351 roped in several men from both sides who had fought in the earlier battle, namely Amiel Bonafos and Johan Aycart for the Vivaut party, and Isnart Eguesier and Peire Carbonel, accompanied by Jacme Bertran, Peire de Jerusalem's chamberlain (chamber famulus) for the Jerusalem. But it was started by two otherwise unknown men, Johan Faber and an Italian named Giovanni di Siena ( Johannes de Sena, italicus).${ }^{96}$ Others fall by the wayside, either by reason of a compromising marriage or for fear of breaking the peace.

Surely some people simply weren't around and would have partici-

95 The Jerusalem surname, so far as I can make out, was unique to the family. The Vivaut surname was carried by a very small number of non-nobles, whom I have excluded from the figures. The very popular Martin surname is much more difficult to disentangle.

96 See ADBR, IIIB 812, fol. $4^{\mathrm{r}}$. 


\section{Table 3 Vivaut Allies and Clients as Named in Two Trials, 1351 and 1356}

\begin{tabular}{ll}
\hline & Accused of conspiracy to murder \\
Fined for battle, $1351^{97}$ & Peire de Jerusalem, 135698 \\
\hline Johan Vivaut & Johan Martin \\
Uguo Vivaut & Bernat Martin \\
Jacme Martin & Johan Aycart, of St. Macello \\
Johan Martin & Peire Fabre \\
Carle Athos & Peire Garin, of St. Macello \\
Guilhem de Montoliu & Guilhem, servant of Johan Martin \\
Amiel Bonafos & Raymon Chauden, squire of Peire Martin \\
Guilhem Martin & Guilhem de Sant Felis and his brother, of Aubagne \\
Johan Aycart & Guilhem Garin, of St. Macello \\
Guilhem Vivaut & Johan Gros and his brother \\
Peire Martin & Raymon Fabre \\
Jacme Englese & Antoni Fabre \\
Laugier de Soliers & Guilhem Viguier \\
Bertomieu Bonvin & Jordan Merlle, of Aubagne \\
Johan de Laureis & Raymon Martin \\
Bernat de Batut & Guilhem Martin \\
Johan Englese & Jacme de Galbert \\
Guilhem de Temple & Peire Bonafos \\
Guilhem Mercier & Amiel Bonafos \\
Esteve de Brandis & Peire Martin, alias Rascas \\
Johan Naulon & Guilhem Mercier \\
Jacme Bonafos & Jacme Mercier \\
Raymon de Laureis & Uguo Ode \\
Peire Amat & Pellegrin Bonpar \\
& Feraut de Barras \\
& Guilhem Vivaut \\
& Girart de Buco \\
& Guilhem Chabert \\
& Esteve de Brandis \\
& Bertran Martin, lord of Rogier \\
& Johan Vivaut \\
\hline & \\
&
\end{tabular}

Note: Duplicate names in boldface.

97 This list is identical to and follows the same order as the list of men condemned to pay fines found in ADBR, IIIB 811, fol. $15^{\mathrm{r}}$.

98 This master list has been gathered from three separate and somewhat overlapping lists found in ADBR, IIIB 820 , fols. $22^{\mathrm{r}}, 23^{\mathrm{r}}$, and $27^{\mathrm{r}}$. I have followed the original ordering, eliminating the duplicates as they cropped up. There are good reasons to believe that the Johan Aycart (of St. Macello) and the Peire Martin (alias Rascas) on the 1356 list are not the same people as those bearing the same names on the 1351 list. 
pated had they been present. But others were losing enthusiasm and, evidently, were being replaced. Feraut de Barras, accused, perhaps falsely, of participating in the conspiracy to murder Peire de Jerusalem, related the following conversation to the judge. He himself had made a peace with his enemy, Peire:

The witness went to Monaco; there, he found Johan Martin and later ran across Amiel Bonafos, who said to him, "You've made a peace with Peire de Jerusalem." The witness said, "Yes, following the wishes of my kinfolk and friends [de voluntate parentum et amicorum meorum]." Having heard this, Amiel did not reply to the witness, but it is nevertheless true that it seemed to him that Amiel never showed him the same good will as he had done before. ${ }^{99}$

The universal peace that followed the battle of 1351 was cited in the later trial by various Vivaut associates as their reason for abandoning the fight. The jurist Primar Mirapeis, for example, reported that he had armed himself for the Vivaut during the "period of battles" [tempore rixarum], but, asked by the judge if he continued to do so, answered, "No, because of the peace" [dixit quod non, propter pacem]. ${ }^{100}$

The peace was not the only reason for the sloughing off of party members. Guilhem Vivaut claimed that he couldn't possibly have been involved in the murder of Peire de Jerusalem: Peire was his brother-inlaw [maxime quia dictus Petrus sororius erat dicti loquentis].$^{101}$ Additional pressure was being placed on those who persevered. Encountering Johan Martin shortly after the murder, Guilhem supposedly said to him, "Johan Martin, you've done ill to come to a place where I am, since I've heard that you murdered Peire de Jerusalem, my in-law." They were visiting the lord of Rupevaria at the time. The lord turned to Johan and said to him, "I am not pleased that you've come to my house; you should go, or else I shall go myself." "Will you at least give me something to drink?" pleaded Johan; he and his associates drank and left. ${ }^{102}$ The old man Peire Bonafos, father of Amiel, also claimed that he had been trying to persuade his son to make peace..$^{103}$

We must make allowance for the circumstances: some of these men were being prosecuted and had every reason to magnify their peaceful qualities. All the same, the tremendous turnover between 1351 and

99 ADBR, IIIB 820, fol. $33^{\mathrm{r}-\mathrm{v}}$.

100 Ibid., fol. $69^{\mathrm{r}-\mathrm{v}}$. See also the testimony of Esteve de Brandis (fol. $71^{\mathrm{v}}$ ). By contrast, see the subsequent testimony of Carle Athos (fol. $74^{\mathrm{v}}$ ) and Uguo Vivaut (fol. $76^{\mathrm{r}}$ ), both of whom reported defiantly that they would continue to arm themselves for their parties.

101 Ibid., fol. $37^{\mathrm{r}}$.

102 Ibid., fol. $37^{\mathrm{v}}$

103 Ibid., fol. $38^{\mathrm{v}}$. 
1356 suggests that there was some truth to what they said. Yet the act of prosecution, because it tended to speak in terms of parties rather than individuals, did not acknowledge the turnover. It had no place, moreover, for individuals like Carle de Montoliu. Married to the niece of Amiel Bonafos, Carle reported that he was not a member of the party, nor had he armed himself for the party [non se armavit nec est de parte], but as an in-law he would of course arm himself on Amiel's behalf. ${ }^{104}$

The very act of prosecution encouraged a group identity. To prosecute the Vivaut party as a group in 1351 was to assume that it was a party and not an assemblage of individuals fighting for their in-laws and masters. This very same group, in defending itself, in allowing itself to be represented by one of its members during the appeal, was forced to develop a common purpose and share a common lot. When Amiel Bonafos and Girart de Buco lodged their appeals in 1356, they searched for witnesses; that search caused them naturally to turn to their old friends, many of whom had kept track of their actions and could say something in their defense. The testimony of two-thirds of the witnesses in Amiel's appeal was subsequently impugned by the clavaire during the rebuttal; he claimed that the testimony should be discounted because they were "partial toward and members of the party of Amiel and the Vivaut" [cum sint et fuerint parciales et de parte dicti Amelii et Vivaudorum]. In this argument there is no possibility that the party was disassembling itself. The antagonisms caused by this point of view may well have encouraged the continuation of party identity and stoked the hatred that fueled that identity.

By using a rigid language of party membership, then, the very act of prosecution played some role in shaping party identity. Even the publicity of court proceedings arguably had a hand in committing people to parties. Reprisals against witnesses, as we have seen, could be severe; the difficulty in finding supposedly impartial witnesses willing to testify may help explain why Amiel Bonafos and Girart de Buco were forced to rely on so many old friends during their appeals. But one must also appreciate the influence of being named as a party member or even a sympathizer during a trial, an act that surely made a future neutrality, especially for the weak, very difficult to achieve.

That fact helps explain one of the most interesting features of the "period of battles": its close proximity to the Black Death of 1348. To judge by the histories outlined above, the bellicose era followed immediately on the heels of the Black Death. The two extant peace ac- 
cords (transcribed in Amiel Bonafos's appeal in 1356) date from March 1350 and July $1351 .{ }^{105}$ The three major appeals and the ten lesser appeals arising from the hatred and found in the extant court records all fall between 1351 and 1356-that despite the fact that the appellate records survive in roughly equal numbers on both sides of the plague. The reasons for that, surely, are complicated. Some can be assigned to the changing ecology of postplague Marseille. In the first decade or so after 1348, resources were both scarce and superabundant, as property values dropped and large amounts of unwanted property were dumped on the market. Labor costs soared. Rent revenue declined. Landlords had difficulty finding tenants or workers for the lands they owned or controlled. Although the sources are too thin to allow us to study how particular families responded to the new ecology, one can easily imagine how the intestine quarrels of Marseille's patriciate may have become inflamed in a struggle to control labor and revenue from rents. Migrants, moreover, moved in great numbers into the city; their connections to the city's social and patronal networks presumably were thin. ${ }^{106}$ The postplague battles themselves can be understood, in part, as recruiting grounds for these and other unconnected people, venues where hard-line party leaders could display party strength and test loyalties.

The courts played a role in the process of recruitment, for the act of prosecution caused identities to become public. That is true in the most banal of ways. Vivaut defendants testifying during the inquisition into the battle of 1351 provided the judge with long lists of Vivaut allies, naming names and describing arms. They were strikingly unable, however, to name the enemy, apart from the well-known figures of Peire de Jerusalem and his captain, Isnart Eguesier, along with the latter's squire. "He could not recognize them," the notary writes during Johan Aycart's testimony, "because they were armed." ${ }^{107}$ The armor was stripped off in court, the faces exposed, the anonymity shattered. The names were inscribed on parchment and publicized in the openair court. Given the dangers one risked as a party member, it was an act that could only cement alliances and rigidify party lines.

\section{Conclusion}

As courts of law responsible to central authorities emerged in medieval Europe in the twelfth and thirteenth centuries, the culture of violence

105 Ibid., fols. $16^{\mathrm{r}}-21^{\mathrm{v}}$.

106 On all these points see my "Accommodating Plague in Medieval Marseille," Continuity and Change 11 (1996): 11-41.

107 ADBR, IIIB 811, fol. $26^{\text {r }}$ : quia armati erant eos cognoscere non potuit. 
that had been so prominent a feature of medieval law and society began to recede. It is easy to assume that the one followed logically from the other. Yet we now know that the process was considerably more complex. Emerging systems of arbitration and peacemaking competed with centralized courts of law for jurisdiction over violence. Many have pointed out that the punishments inflicted in the name of law and order are no less violent than those pursued in the name of vengeance, that law and vengeance are less distinct than we once thought. Litigation has been recognized as a form of revenge. ${ }^{108}$ In studying the comparatively new judicial system of Angevin Marseille, this article has added yet another qualifying perspective: courts of judicial inquisition, at an early stage of their evolution, did not necessarily repress violence as quietly and as easily as we used to think.

Judicial intervention, of course, did not create the factional hatreds that wracked Angevin Marseille in the decades around the Black Death of 1348. Instead, the courts contributed to a hardening of existing but ill-defined boundaries. They did so by unwittingly encouraging the telling of histories that served to anchor people in the past and provide them with an identity in the present. They did so by acting as venues for the pursuit of vengeance and by undermining the possibilities of peace. They did so by creating or encouraging a language of party membership. In all those ways, the courts promoted, rather than repressed, dissension and strife. The best we can say is that the courts eventually made vengeance less bloody and more stylized; after the 1350 s, the great Vivaut/Jerusalem hatred becomes less visible, at least in the court records. The courts offered the wrathful a chance to satisfy their cravings for vengeance without risking life and limb. In that civilizing process, though, the courts were not the primary agents of change. In search of a deeper understanding, we should look to the understanding shared by all that blood vengeance can be costly and undesirable. ${ }^{109}$ Traces of this discomfiture crop up in the sourceswhen the old men, for example, try to persuade their sons to leave off the battles and make peace, or when kinfolk and friends urge the bellicose to uphold a peace. The courts, then, can be seen as witnesses to a larger transformation in late medieval habits of hatred and peacemaking. It was a transformation the courts and their agents may have influenced profoundly, but one that they did not direct.

108 James A. Sharpe, “'Such Disagreement betwyx Neighbours': Litigation and Human Relations in Early Modern England,” in Disputes and Settlements, ed. Bossy, 167-87; Richard L. Kagan, Lawsuits and Litigants in Castile, 1500-1700 (Chapel Hill, N.C., 1981).

109 See Muir, Mad Blood Stirring. 